研究

\title{
$\mathrm{RF}$ 反応スパッタ法による Al-O-N コーティング膜の作製
}

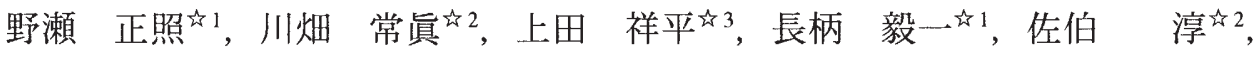 \\ 松田 健二的 2 , 寺山 清的 2 , 池野進的2 \\ 的1 富山大学芸術文化学部, 干933-8588 高岡市二上町 180 . \\ 和富山大学大学院理工学研究部, 干 930-8555 富山市五福 5190 . \\ 的 3 富山大学大学院理工学教育部, $=930-8555$ 富山市五福 5190.
}

\section{Preparation of Al-O-N Coatings by r.f. Reactive Sputtering}

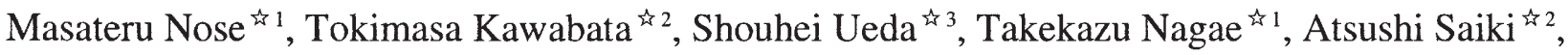 \\ Kenji Matsuda $^{\text {मे } 2}$, Kiyoshi Terayama ${ }^{\text {is } 2}$ and Susumu Ikeno ${ }^{\text {मे } 2}$ \\ is 1 Faculty of Art \& Design, University of Toyama, 180 Futagami-cho, Takaoka 933-8588, Japan. \\ ${ }^{4}{ }^{2}$ Graduate School of Science and Engineering for Research, University of Toyama, 5190 Gofuku, Toyama 930-8555, Japan. \\ ${ }^{4} 3$ Graduate Student, Graduate School of Science and Engineering for Education, University of Toyama, 5190 Gofuku, Toyama 930-8555, Japan.
}

Received July 4, 2008

\section{SYNOPSIS}

The influence of sputtering conditions on the microstructure and mechanical properties of Al-O-N films was investigated using XRD, TEM and nano-indentation. The targets of sintered $\mathrm{Al}_{2} \mathrm{O}_{3}$ plate were sputtered in a mixture of argon and nitrogen using an r.f. sputtering apparatus of facing target-type sputtering. Nitrogen gas flow rate was controlled from 0 to $40 \mathrm{sccm}$ under the fixed Ar gas flow rate $(10 \mathrm{sccm})$. The substrate was heated up to $\sim 300^{\circ} \mathrm{C}$. The highest hardness of $27 \mathrm{GPa}$ was obtained for the $\mathrm{Al}-\mathrm{O}-\mathrm{N}$ film deposited at $300^{\circ} \mathrm{C}$ under 30 sccm of the nitrogen gas flow rate, which value is almost twice that of $\mathrm{Al}-\mathrm{O}$ films.

$\mathrm{XRD}$ and SAED analysis of Al-O-N films suggested the existence of some phases; hcp-AlN, AlON and $t-\mathrm{Al}_{2} \mathrm{O}_{3}$ phase may presented in the film. The dark-field TEM images of the Al-O-N films revealed that the film consists of very fine grains of $\sim 6 \mathrm{~nm}$ in diameter.

The Al-O-N film having the highest hardness has higher transparency of visible light than that of $\mathrm{Al}-\mathrm{O}$ films. Even if the Al-O-N films was annealed up to $800^{\circ} \mathrm{C}$ for 1 hour in the air, mechanical properties were not changed, but decreased drastically after the annealing at $900^{\circ} \mathrm{C}$.

KEY WORDS

$\mathrm{AlON}$, h-AlN, $\mathrm{Al}_{2} \mathrm{O}_{3}$, reactive sputtering, nano-indentation, X-ray diffraction, TEM

\section{1 緒言}

アルミナ $\left(\mathrm{Al}_{2} \mathrm{O}_{3}\right)$ は典型的な多形で, 最も優れた機械的性質 を示すのは $\alpha-\mathrm{Al}_{2} \mathrm{O}_{3}$ である.この $\alpha-\mathrm{Al}_{2} \mathrm{O}_{3}$ の膜は耐酸化性お よび耐摩耗性に優机るため, 切削工具などの硬質保護膜とし て使用されている. しかし， $\alpha-\mathrm{Al}_{2} \mathrm{O}_{3}$ の膜を得るためには基 板温度を $1000^{\circ} \mathrm{C}$ 以上にする必要がある1.2) とされ, 通常のPVD 装置を用いての成膜は困難である. 基板温度が $500^{\circ} \mathrm{C}$ 以下の 場合には $\mathrm{Al}_{2} \mathrm{O}_{3}$ 膜はアモルファスライク構造をとり, その塑 性硬さは約 $10 \mathrm{GPa}$ 程度となることが知られている. 他方, AlN は高い熱伝導性と優れた電気絶縁性によって半導体用基板へ の応用 ${ }^{3)}$ を心に研究されており, 薄膜に関してはその誘電 特性に着目した研究が多い ${ }^{4-6)}$.
一方, $\mathrm{Al}-\mathrm{O}-\mathrm{N}$ 焼結体は透光性に優れるとともに, 高温下 でも優れた機械的性質を示すとされ，発光管材料や高温空用 材料としての応用が検討されている7. またAl-O-N膜につい ては, 1990 年代から反応スパッ夕法帛やイオン注入法" で成膜の試みが始まっているが, 主にその透光性, 電気特性, 化学特性などに着目して研究されている(10-14). しかし, Al-O$\mathrm{N}$ 膜の機械的性質に関する研究は少なく, $\mathrm{Al}$ 蒸発源と $\mathrm{O}_{2} や \mathrm{~N}_{2}$ などの反応性ガスを用いた PVD法による Al-O-N膜の作製と その光学的性質に加えて膜の塑性硬さについて言及した報 告 ${ }^{15,16)}$ がわずかにみられる程度である. $\mathrm{Al}$ ターゲットと $\mathrm{O}_{2}$, $\mathrm{N}_{2}$ および $\mathrm{Ar}$ の混合ガスを用いた反応スパッ夕法の場合には $\mathrm{O}_{2}$ と $\mathrm{N}_{2}$ の $\mathrm{Al}$ に対する反応性の差が大きいため, $\mathrm{O}, \mathrm{N}$ 濃度の 
制御が困難である.

そこで本研究では, $\mathrm{Al}_{2} \mathrm{O}_{3}$ ターゲットと $\mathrm{N}_{2}$ と $\mathrm{Ar}$ の混合ガス を用いた反応スパッ夕法により $\mathrm{Al}-\mathrm{O}-\mathrm{N}$ 膜の作製を試み，ス パッ夕条件と得られた膜の特性との関係を調べた。

\section{2 試料および実験方法}

2.1 試料作製条件

膜作製に使用した装置は対向ターゲット式マグネトロンス パッ夕装置 (大阪真空機器製作所製 FTS-R2)である。本実験 では，スパッ夕電源に高周波(R.F) 電源を用いた. R.F 電源に は共振周波数 $13.56 \mathrm{MHz}$ ，最大出力 $1 \mathrm{~kW}$ のものを使用した. 蒸着源には焼結 $\mathrm{Al}_{2} \mathrm{O}_{3}$ ターゲット $(100 \times 160 \mathrm{~mm}, 99.5 \%)$ を用 いた。 スパッタガスには Ar (99.9999\%), 反応ガスには $\mathrm{N}_{2}$ (99.9999\%), 基板にはSiウェハー(100), 透明石英板を用いた.

複合分子ポンプによりスパッタ室を $5.0 \times 10^{-5} \mathrm{~Pa}$ 以下まで真 空排気した後, $\mathrm{Ar}$ と $\mathrm{N}_{2}$ ガスを導入し, マスフローコントロー ラを用い, Arを $10 \mathrm{sccm}$ 一定， $\mathrm{N}_{2}$ 流量を 5 25 sccmにそれぞ れ制御してスパッ夕成膜した。 そのときのスパッタガス圧は 0.2 0.5 Paであった. ターゲット一基板間距離は $115 \mathrm{~mm}$ 一定 とし，成膜時の基板温度は室温 $300^{\circ} \mathrm{C}$ の温度範囲で制御し た。 スパッ夕電力は $1 \mathrm{~kW}$ 一定とし, 膜厚が $2 \sim 2.3 \mu \mathrm{m}$ となる ように成膜時間を制御した。

\section{2 各種測定と評価}

膜厚は表面形状測定器 (ミツトヨ製)によって測定した. 波 長分散型 EPMA (日本電子製 JAX-8600) を使用し，組成分析 を行った．測定の際には加速電圧 $10 \mathrm{kV}$ ，試料電流 $50 \mathrm{nA}$ ，照 射ビーム径 $5 \mu \mathrm{m}$ とした. 膜の微小硬度測定には超マイクロイ ンデンター(フィッシャー製 $\mathrm{HC}-100 \mathrm{XYp}$ ) を用い，膜中への 圧子の侵入深さが膜厚の概ね 10 分の 1 以下となるように最高 荷重を選んだ．除荷曲線の接線から圧子の侵入深さを求め, 接触面積に換算することによって塑性変形硬さ $\left(\mathrm{H}_{\mathrm{pl}}\right)$ を計算す

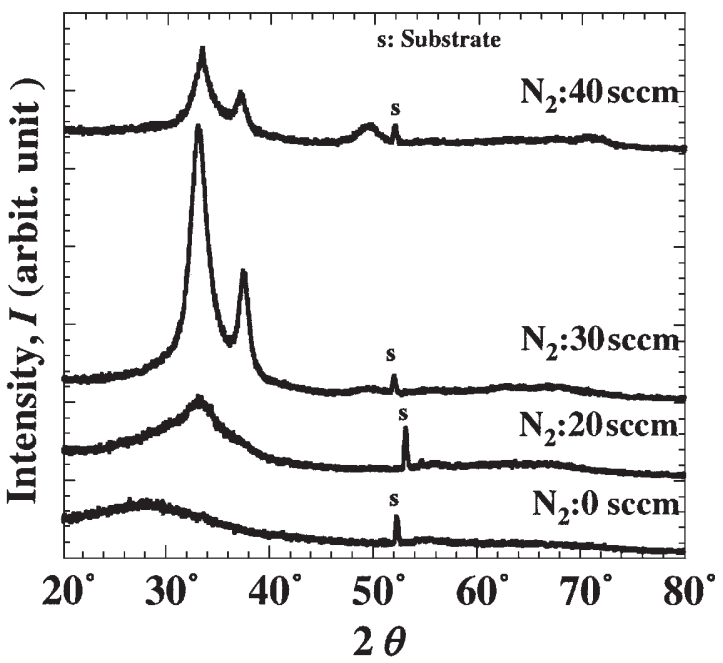

Fig.1 XRD patterns for AlON films deposited at different $\mathrm{N}_{2}$ flow rate: r.f. power $=1 \mathrm{~kW}, \mathrm{Ar}=10 \mathrm{sccm}$, substrate temperature, $\mathrm{T}_{\mathrm{s}}: \sim 300^{\circ} \mathrm{C}$
る Oliverの方法 ${ }^{17)}$ を用いた。試料の構造解析には，X 線回折 装置 (Philips 製X'part system) を使用し，薄膜法(入射角 $1^{\circ}$ ) を 用いた。 X 線源には $\mathrm{CuK} \alpha$ 線 $(40 \mathrm{kV}, 40 \mathrm{~mA})$ を用い，結晶粒 サイズの測定には，Scherrerの式を用いた．また，膜の微細 組織観察には TEM (Topcon, EM002B) を用いた。

\section{3 実験結果および考察}

\section{1 結晶構造と機械的性質}

$\mathrm{Ar}$ 流量を $10 \mathrm{sccm}$, 基板温度を $300^{\circ} \mathrm{C}$ とれれ゙れ一定にし， $\mathrm{N}_{2}$ 流量を0〜40 sccmの範囲で制御して成膜を行った. Fig.1に $\mathrm{N}_{2}$ 流量をパラメータとして作製した Al-O-N 膜の X 線回折 (薄膜法) パターンの変化示す。スパッ夕雾囲気が $\mathrm{Ar}$ のみ 場合は, $2 \theta=30^{\circ}$ 付近にブロードなピークを持つハローパター ンを示すが, $\mathrm{N}_{2}$ 流量が $20 \mathrm{sccm}$ 以上になると, $34^{\circ}$ 付近に明確 なピークが現れ， $30 \mathrm{sccm}$ 以上では $38^{\circ} や 49^{\circ}$ 付近にもピーク が見られる.さらに $40 \mathrm{sccm}$ で作製した膜には $72^{\circ}$ 付近にも弱 いピークが見られる.これらの内， $2 \theta=30^{\circ}, 38^{\circ}, 72^{\circ}$ のピーク はほぼ hcp の AlN のピーク位置に対応するが, $49^{\circ}$ のピーク に該当する $\mathrm{AlN}$ ピークは存在しない.なお， $52^{\circ}$ または $53^{\circ}$ 付 近にみられる弱いが鋭いピークは基板のSi単結晶からのピー クであることを,膜なしの基板のXRDパターンから確認して いる，これらのピークが現れる原因は不明であるが，回折法 には低角入射法 (入射角 1 度)を採用しているために, 単結晶 の場合，多重反射などが生じ，基板のセット方向によって現 れる反射ピークが異なるものと推测される.いずれにしても, これらのピークは膜の構造とは無関係である.

次にAr流量および $\mathrm{N}_{2}$ 流量をそれぞれ $10 \mathrm{sccm}$ おび $30 \mathrm{sccm}$ 一定にし，基板温度を室温 $300^{\circ} \mathrm{C}$ の範团で制御して成膜を 行った. Fig.2 に基板温度をパラメータとして作製した Al-O$\mathrm{N}$ 膜の X 線回折 (薄膜法)パターンの変化示す. 基板温度が室 温から $150^{\circ} \mathrm{C}$ までは，パターンにほとんど変化は見られず,

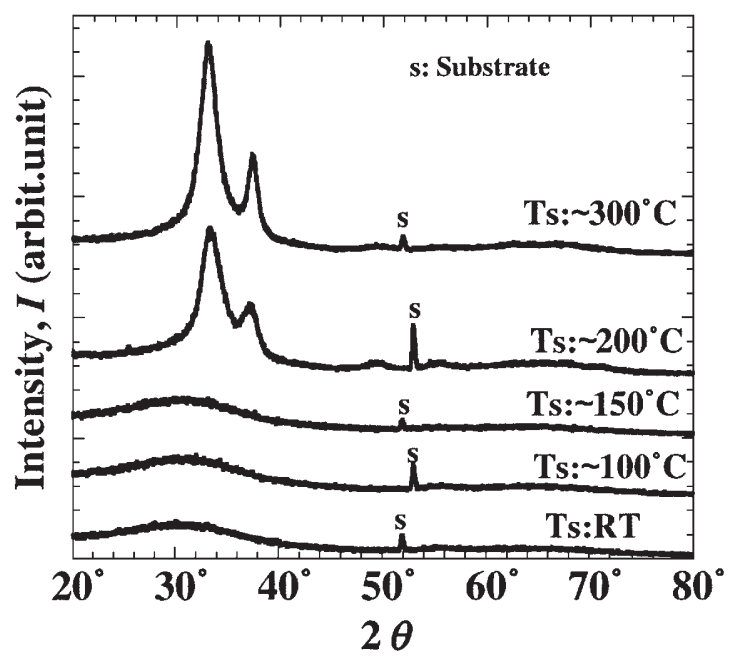

Fig.2 XRD patterns for AlON films deposited at different substrate temperature: r.f. power: $1 \mathrm{~kW}, \mathrm{Ar}=10 \mathrm{sccm}, \mathrm{N}_{2}=$ $30 \mathrm{sccm}$. 
いずれも $2 \theta=30^{\circ}$ 付近にブロードなピークを持つハローパ ターンである．ところが，基板温度が $200^{\circ} \mathrm{C}$ になると， $34^{\circ}$, $38^{\circ}$ の強いピークの他, $49^{\circ}$ 付近にも弱いピークが現れる. 半 価幅から計算される試料面に垂直な力向に測った結晶子サイ ズは約 $4 \mathrm{~nm}$ であった．さらに基板温度が $300^{\circ} \mathrm{C}$ になると，主 ピークの強度が上がり, 半価幅も2.56度から2.36度に低下し, 結晶子サイズが若干大きくなったことを示している.

Fig. 3 に，Ar 流量 $10 \mathrm{sccm}$ ，基板温度 $300^{\circ} \mathrm{C}$ の条件を一定に し， $\mathrm{N}_{2}$ 流量を 0〜 $40 \mathrm{sccm}$ の範囲で作製した Al-O-N膜の塑性 硬さ及びヤング率に及ぼす $\mathrm{N}_{2}$ 流量の影響を示す。 $\mathrm{N}_{2}$ 流量が $0 \mathrm{sccm}$ の場合は得られた $\mathrm{Al}-\mathrm{O}$ 膜 $\left(\mathrm{Al}_{\mathrm{x}} \mathrm{O}_{\mathrm{y}}\right)$ は $\mathrm{Al}_{2} \mathrm{O}_{3}$ に比べて酸 素濃度の低い膜になっていると考えられ, 塑性硬さは約 $14 \mathrm{GPa}$ である. $\mathrm{N}_{2}$ 流量が $20 \mathrm{sccm}$ までは塑性硬さおよびヤング率に 変化がほとんど見らないが, $30 \mathrm{sccm}$ では塑性硬さ,ヤング率 ともに急激に上昇する．とくに $300^{\circ} \mathrm{C}$ で作製した膜の塑性硬 さは $27 \mathrm{GPa}$ となり，窒素なしの場合のほぼ2倍に増大するこ とが分かる. $\mathrm{N}_{2}$ 流量がさらに増加すると塑性硬さは $24 \mathrm{GPa}$ と 若干低下する傾向を示す．他方ヤング率は $\mathrm{N}_{2}$ 流量 $30 \mathrm{sccm}$ 以 上でほぼ一定の $200 \mathrm{GPa}$ を示す. Fig.4に, Ar流量 $10 \mathrm{sccm}, \mathrm{N}_{2}$ 流量を $30 \mathrm{sccm}$ 一定にし，基板温度をパラメータとして作製 した Al-O-N膜の塑性硬さ及びヤング率に及ぼす基板温度の 影響を示す．基板温度が $150^{\circ} \mathrm{C}$ までは塑性硬さ，ヤング率と もにほとんど変化が見られないが，200ํㅡㄴでは塑性硬さ は 26〜27 GPa，ヤング率は 190〜200 GPa と急激な上昇を示 した.この值はすでに述べたようにAl-O膜の塑性硬さ $14 \mathrm{GPa}$ や文献值による AlN 膜の塑性硬さ $10 \sim 15 \mathrm{GPa}$ に比べても約 2 倍の高い值である.

以上の結果から, $\mathrm{N}_{2}$ 流量が $30 \mathrm{sccm}$, 基板温度が $200 \sim 300^{\circ} \mathrm{C}$ の条件下で作製した Al-O-N膜が機械的性質に優れることが 分かった. Table 1 は $\mathrm{N}_{2}$ 流量 $30 \mathrm{sccm}$, 基板温度が $200^{\circ} \mathrm{C}$ で作 製したAl-O-N膜のEPMA分析結果を示す. $\mathrm{Al}$ とガス元素 $(\mathrm{O}$, N)の比は, 約 $2.2: 2.9$ であり, ターゲット材の $\mathrm{Al}_{2} \mathrm{O}_{3}$ の場合の

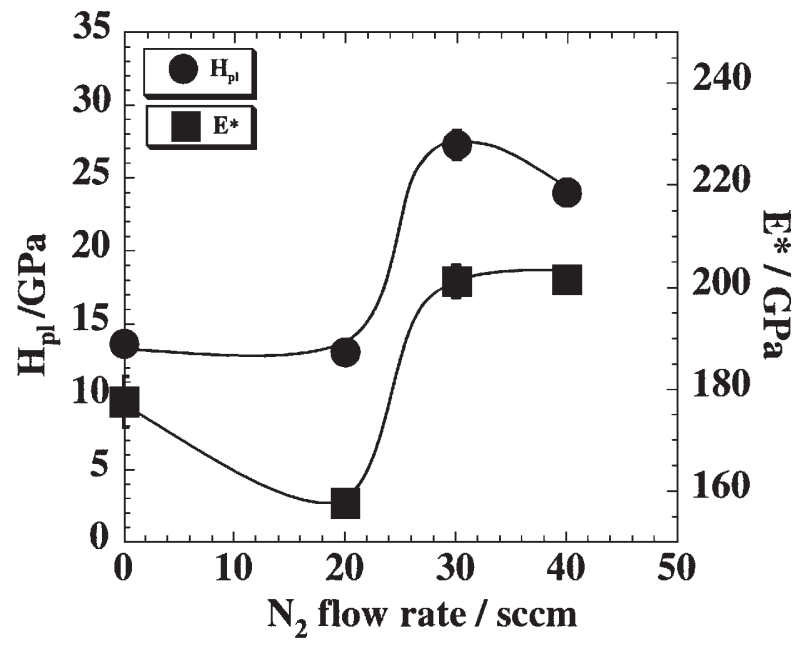

Fig.3 Variation of plastic hardness $\left(\mathrm{H}_{\mathrm{pl}}\right)$ and Young's modulus $\left(\mathrm{E}^{*}\right)$ with $\mathrm{N}_{2}$ flow rate: $r$.f. power $=1 \mathrm{~kW}, \mathrm{Ar}=10 \mathrm{sccm}$, substrate temperature, $\mathrm{T}_{\mathrm{s}}: \sim 300^{\circ} \mathrm{C}$.
$2: 3$ に近い組成比になっていることが分かる.

Fig.5 は Table 1 に示した Al-O-N 膜 (平面試料) の TEM 明 視野像亡制限視野回折図形である. $10 \mathrm{~nm}$ 以下の微細な結晶 粒からなる膜であることが一見してわかる. 最も内側の回折 リングから得た暗視野像により特定した結晶粒を実線で取り 囲んで示す。平均すると約 $6 \mathrm{~nm}$ であった. Table 2 に制限視 野回折図形およびXRD パターンのピーク位置とJCPDS カー ドによる $\mathrm{AlN}, \boldsymbol{l}-\mathrm{Al}_{2} \mathrm{O}_{3}$ および $\mathrm{AlON}$ との対応を示す。なお比 較を容易にするために, 制限視野回折図形およびJCPDS力ー ドからの面間隔デー夕を $\mathrm{CuK} \alpha$ 線による回折ピーク位置に換 算して示した。回折リングは(3)を除いて概ね AIN と一致す

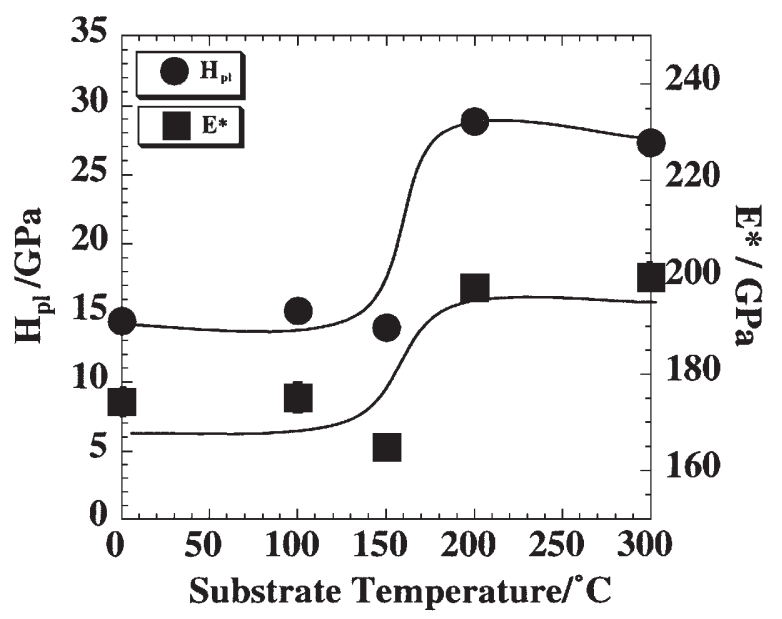

Fig.4 Variation of plastic hardness $\left(\mathrm{H}_{\mathrm{pl}}\right)$ and Young's modulus $\left(\mathrm{E}^{*}\right)$ with substrate temperature: r.f. power: $1 \mathrm{~kW}, \mathrm{Ar}=10$ sccm, $\mathrm{N}_{2}=30 \mathrm{sccm}$

Table 1 Composition of Al-O-N film showing highest hardness (deposited at $\mathrm{Ar}=10 \mathrm{sccm}, \mathrm{N}_{2}=30 \mathrm{sccm}, \mathrm{T}_{\mathrm{s}}=200^{\circ} \mathrm{C}$ ).

\begin{tabular}{|c|c|c|c|c|}
\hline & $\mathrm{Al}$ & $\mathrm{O}$ & $\mathrm{N}$ & Total \\
\hline $\begin{array}{c}\text { Atomi } \\
\mathrm{c}(\%)\end{array}$ & $42.9 \pm 0.2$ & $25.0 \pm 0.1$ & $32.1 \pm 0.2$ & 100.0 \\
\hline
\end{tabular}

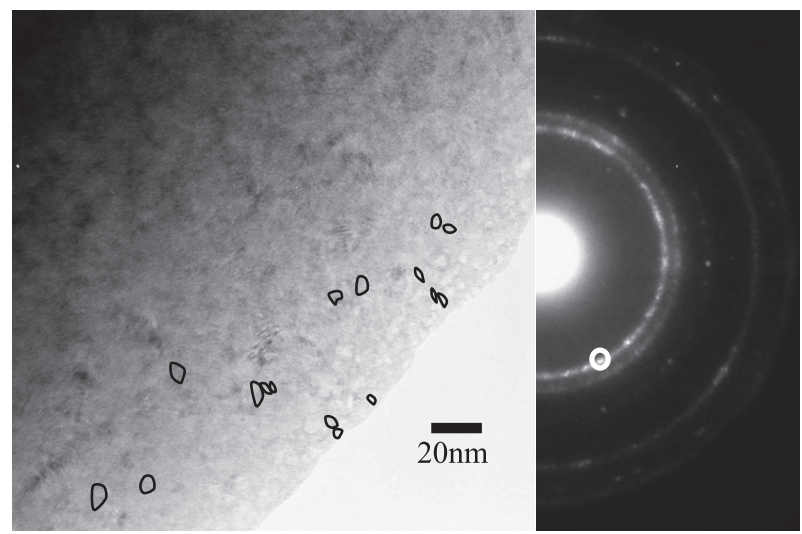

Fig.5 Plane-view of TEM micrograph and corresponding electron diffraction pattern of Al-O-N film $\left(\mathrm{Ar}=10 \mathrm{sccm}, \mathrm{N}_{2}=30\right.$ sccm, $\mathrm{T}_{\mathrm{s}}: \sim 200^{\circ} \mathrm{C}$ ). 
Table 2 Comparison of peak positions of XRD chart, SAED pattern for $\mathrm{Al}-\mathrm{O}-\mathrm{N}$ films and JCPDS data.

\begin{tabular}{|c|c|c|c|c|c|}
\hline & TEM & XRD & $\begin{array}{c}\text { AlN } \\
25-1123\end{array}$ & $\begin{array}{l}l-\mathrm{Al}_{2} \mathrm{O}_{3} \\
12-0539\end{array}$ & $\begin{array}{c}\text { AlON } \\
48-1580\end{array}$ \\
\hline & - & - & & (4) & (1) \\
\hline \multirow[t]{2}{*}{ (1) } & 33.67 & 33.36 & 33.216 & & 33.981 \\
\hline & - & - & & (2) & $(5)$ \\
\hline \multirow[t]{2}{*}{ (2) } & 37.71 & 37.39 & 37.916 & & 37.489 \\
\hline & - & - & & $(5)$ & $(7)$ \\
\hline \multirow[t]{2}{*}{ (3) } & 46.89 & - & & & 46.762 \\
\hline & - & - & & (1) & \\
\hline \multirow[t]{3}{*}{ (4) } & - & 49.38 & 49.814 & & 49.098 \\
\hline & & & & & 50.195 \\
\hline & - & - & & (2) & (3) \\
\hline \multirow[t]{2}{*}{ (5) } & 60.15 & - & 59.349 & 59.597 & 60.720 \\
\hline & - & - & & (2) & (3) \\
\hline \multirow[t]{4}{*}{ (6) } & 67.61 & - & 66.052 & 66.227 & 67.306 \\
\hline & - & - & (1) & (1) & (2) \\
\hline & - & 70.64 & & & 70.783 \\
\hline & - & - & (1) & & $(1)$ \\
\hline (7) & 72.13 & - & 72.627 & 73.460 & 72.868 \\
\hline
\end{tabular}

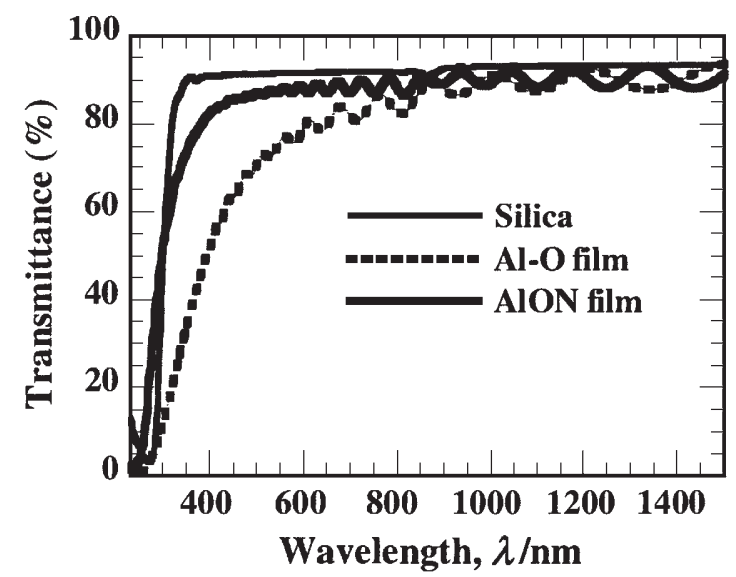

Fig.6 Transmittance spectra of AlON and alumina film $(\sim 2 \mu \mathrm{m})$ deposited on fused silica substrate.

る.他方, XRD ピークについては第二ピークよりも広角側の ピークが制限視野回折リングとも一致しない. 他方AIN とは ピーク (1)，(2)，(4)が一致するが，それ以上の広角側では AIN ピークには合致しない.これら外側のピークはAION (JCPDS 48-1580) とほぼ一致するが，菱面体構造の AlONが持つその 他のピーク (存在する角度範囲欄に（）の数字でピーク数を 表示)がXRDパターンでも制限視野回折図形でも全く見られ ないことから, 菱面体構造を有すると早計に断定することは できない.またこれらのピークは $\iota-\mathrm{Al}_{2} \mathrm{O}_{3}$ (JCPDS 12-0539)の ピークともほぼ一致するものがあり(5), (6), (7) $\mathrm{AlN}_{2} \iota-\mathrm{Al}_{2} \mathrm{O}_{3}$ の混合相の可能性も否定できない，いずれにしても結晶構造 の同定については今後さらに詳細な検討を要する.

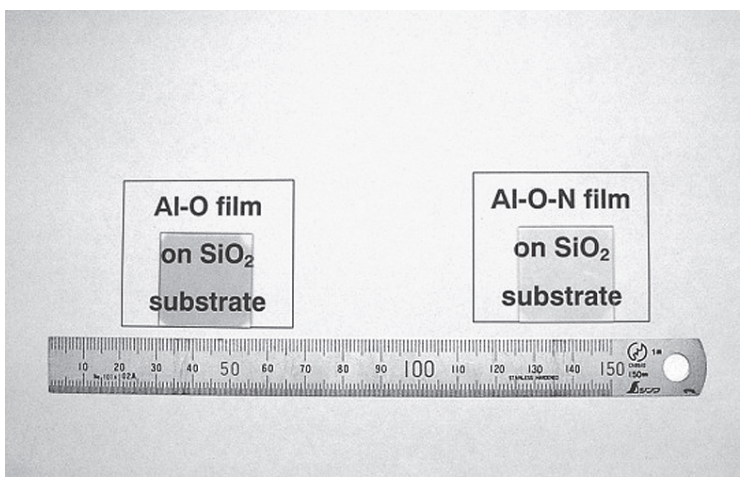

Fig.7 Appearance of $\mathrm{Al}-\mathrm{O}$ and $\mathrm{Al}-\mathrm{O}-\mathrm{N}$ ilms deposited on fused silica substrate: (a) $\mathrm{Al}-\mathrm{O}$ film, (b) $\mathrm{Al}-\mathrm{O}-\mathrm{N}$ film.

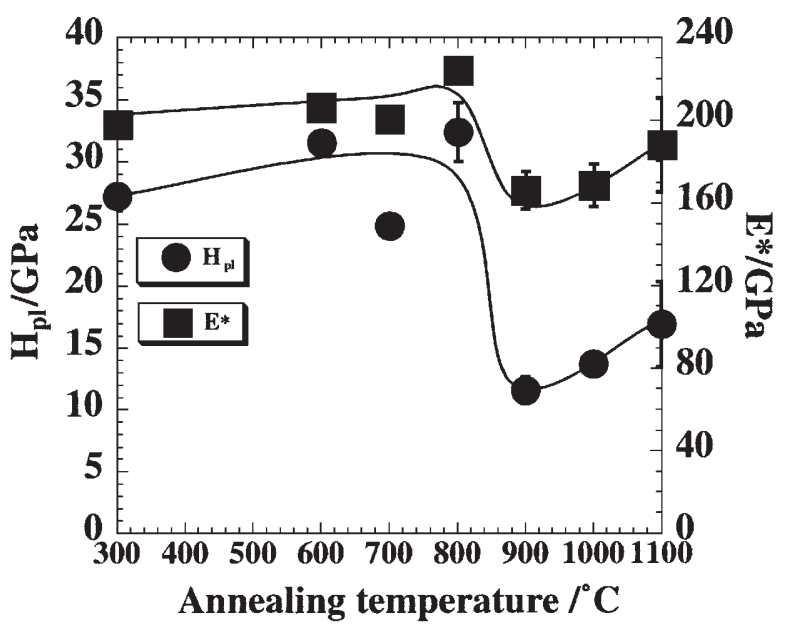

Fig.8 Variation of plastic hardness $\left(\mathrm{H}_{\mathrm{pl}}\right)$ and Young's modulus $\left(\mathrm{E}^{*}\right)$ with annealing temperature: $r$.f. power $=1 \mathrm{~kW}, \mathrm{Ar}=10$ $\mathrm{sccm}, \mathrm{N}_{2}=30 \mathrm{sccm}$, substrate temperature, $\mathrm{T}_{\mathrm{s}}: \sim 200^{\circ} \mathrm{C}$.

以上のように, 本研究で作製した Al-O-N 膜は明らかにア ルミニウムや酸素の他に窒素を含み, 非晶質の $\mathrm{Al}-\mathrm{O}$ 膜や hcpAlN 膜の約 2 倍の塑性硬さを有する. このような機械的性質 の大幅な向上は, $\mathrm{Al}_{2} \mathrm{O}_{3}$ の酸素の一部を窒素で適度に置換する と同時に, 膜が非晶質構造ではなく $10 \mathrm{~nm}$ 以下のナノメータ オーダーの微細な結晶粒で構成されていることによるものと 考えられる.

3.2 光学特性と耐熱性

Fig.6に透明石英板上に基板温度 $200^{\circ} \mathrm{C}$ で厚さ約 $2.0 \mu \mathrm{m}$ で成 膜したAl-O-N膜およびAl-O膜試料の透過率のスペクトルを 示す. 膜厚が約 $2.0 \mu \mathrm{m}$ あるため, 石英基板との間で光の干渉 を起こしスペクトルに周期変動がみられるが, 明らかに可視 光領域 $(400 \mathrm{~nm} \sim 800 \mathrm{~nm})$ の透過率は Al-O 膜よりも高いこと がわかる. Fig.7は透過光スペクトルを測定した試料の外観写 真である. 明らかに Al-O-N膜試料の方が Al-O膜試料よりも 透明度が高いことがわかる。

Fig. 8 はこの Al-O-N 膜を大気中 $600 \sim 1200^{\circ} \mathrm{C}$ の各温度で 1 時間加熱後空冷し, 室温で測定したその膜の塑性硬さ及び 
ヤング率と加熱温度との関係を示す.デー夕に多少ばらつき が見られるが $800^{\circ} \mathrm{C}$ までは 1 時間の大気中加熱によって機械 的性質はあまり変化しないことがわかる。他方, $900{ }^{\circ} \mathrm{C}$ 以上 の加熱で塑性硬さ, ヤング率ともに急激に低下している。こ れらの試料の XRD パターンを Fig.9 に示す. Al-O-N 膜の第 1 および第2ピークの幅は $900^{\circ} \mathrm{C}$ まで殆ど変化しないが, $900^{\circ} \mathrm{C}$ の加熱では $62^{\circ}$ 付近に鋭いピークが現れる.これがどのよう な物質の生成を示すのかは今のところ不明であるが, 基板が $\mathrm{Si}$ であること，およびJSPDS カードのデータなどから, $\mathrm{SiO}_{2}$ の生成に対応するのではないかと考えられる.さらに $1100^{\circ} \mathrm{C}$ で加熱した膜では，Al-O-N のピークは消失し，ほぼ完全な $\alpha-\mathrm{Al}_{2} \mathrm{O}_{3}$ 相のピークのみが見られる.これはAl-O-Nが高温で 酸化され, 膜中の窒素が酸素に置換されると同時に高温で安 定な相である $\alpha$ アルミナに変化したものと考えられる.

以上のように，本研究で作製した Al-O-N 膜は高い透明性 を有し, $800^{\circ} \mathrm{C} \times 1$ 時間の大気中加熱でも機械的性質がほとん ど変化しない, 優れた耐熱性を有する膜であることが分かる.

\section{4 ま と め}

$\mathrm{Al}_{2} \mathrm{O}_{3}$ ターゲットと $\mathrm{Ar}$ および $\mathrm{N}_{2}$ の混合ガスによる高周波反 応スパッ夕法を用いて， Al-O 膜および Al-O-N 膜を作製し， それらの構造と機械的性質におよぼすスパッ夕条件の影響を 調べた結果，以下のことが明らかになった.

(1) $\mathrm{Al}-\mathrm{O}$ 膜および $150^{\circ} \mathrm{C}$ 以下で成膜した $\mathrm{Al}-\mathrm{O}-\mathrm{N}$ 膜は，アモ ルファスライクな構造を示し，これらの膜の機械的性質 はほぼ同等であった。

（2）基板温度 $200^{\circ} \mathrm{C}$ 以上, $\mathrm{Ar}$ 流量 $10 \mathrm{sccm}$ 一定, $\mathrm{N}_{2}$ 流量 $30 \mathrm{sccm}$ の条件下で成膜した Al-O-N 膜は約 $6 \mathrm{~nm}$ の微結晶からな り, 塑性硬さは約 $27 \mathrm{GPa}$ に達し, $\mathrm{Al}-\mathrm{O}$ 膜の約 2 倍の高い 値を示した。

(3) 可視光の透過率は Al-O 膜よりも高い.

(4) 高い硬度を示した $\mathrm{Al}-\mathrm{O}-\mathrm{N}$ 膜では， $800^{\circ} \mathrm{C} \times 1$ 時間の大気 中加熱でも，機械的性質はほとんど低下しなかったが, $900^{\circ} \mathrm{C}$ 以上で急激に低下した.

\section{謝辞}

本研究の一部は, 平成 19 年度科学研究費補助金 (萌芽研究) によって行われたものであり,JSPSならびに関係者各位に感 謝の意を表する.また, TEM試料のイオンミリングにご協力 いただいた富山工業高等専門学校 坂本佳紀氏に感謝する.

\section{文献}

1) T. Kohara, H. Tamagaki, Y. Ikari, and H. Fujii: "Deposition of $\alpha-\mathrm{Al}_{2} \mathrm{O}_{3}$ hard coatings by reactive magnetron sputttering", Surf. Coat. Technol., 185(2004)166-171.

2) M. Åstrand, T. I. Selinder, F. Fietzke, and H. Klosermann: "PVD- $\mathrm{Al}_{2} \mathrm{O}_{3}$-coated cemented carbide cutting tools", Surf. Coat. Technol., 188-189(2004)186-192.

3) The Ceramics Society of Japan: "Handbook of Ceramics

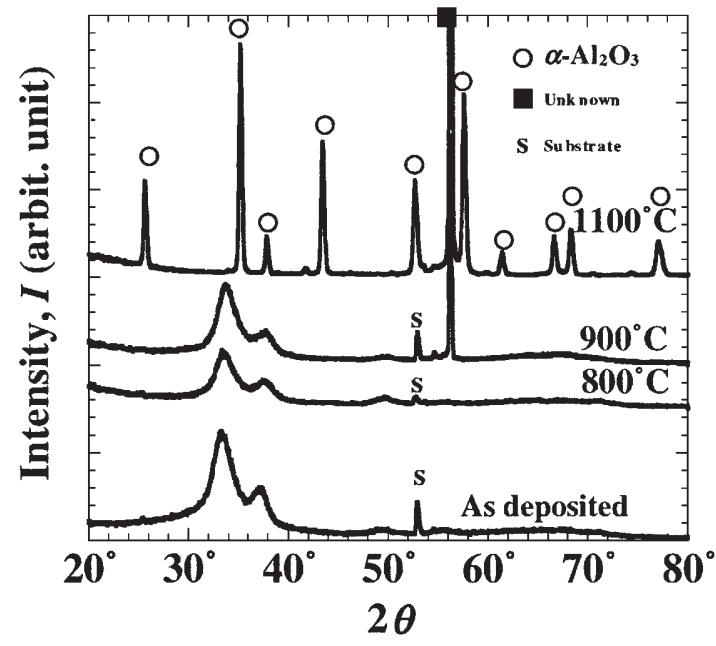

Fig.9 Fig. XRD patterns for AlON films deposited at different annealing temperature: r.f. power $=1 \mathrm{~kW}, \mathrm{Ar}=10 \mathrm{sccm}, \mathrm{N}_{2}=$ $30 \mathrm{sccm}$, substrate temperature, $\mathrm{T}_{\mathrm{s}}: \sim 200^{\circ} \mathrm{C}$.

[Application]", 2nd Edition, Gihodo Shuppan (Tokyo), (2002) 916-919.

4) H.-C. Lee, G.-H. Kim, S.-K. Hong, K.-Y. Lee, Y.-J. Yong, C.-H. Chun, and J.-Y. Lee: "Influence of sputtering pressure on the microstructure evolustion of AlN thin films prepared by reactive sputtering", Thin Solid Films, 261(1995) 148-153.

5) B. Abdallah, A. Chala, P.-Y. Jouan, M.P. Besland, and M.A. Djouadi: "Deposition of AIN films by reactive sputtering: Effect of radio frequency substrate bias", Thin Solid Films, 515(2007)7105-7108.

6) J. Adamczyk, N. Horny, A. Tricoteaux, P.-J. Jouan, and M. Zadam: "On the use of response surface methodology to predict and interpret the preferred c-axis orientation of sputtered AlN films", Applied Surface Science, 254(2008)1744-1750.

7) W.Xidong, W.Fuming, and L.Wenchao: "Synthesis, microstructures and properties of $\gamma$-aluminum oxynitride", Materials Science and Engineering, A342(2003)245-250.

8) W.Dehuang and G.Liang: "An aluminum oxynitride film", Thin Solid Films, 198(1991)207-2103.

9) M. Jacobs and F. Bodart: "Depth profiles in SiON and AlON thin films produced by ion implantation", Nuclear Instruments and Methods in Physics Research B, 118(1996)714-717.

10) Ch. Täschner, J. Klosowski, A. Leohardt, and U. Dümichen: "Plasma enhanced deposition of titanium aluminum composite films using organometallic aluminum precursors", Surf. and Coat. Technol., 98(1998)925-933.

11) V.M. Berudez: "Study of the chemistry of $\mathrm{NH}_{3}$ on aluminum nitride and oxynitride under steady-state conditions using external-reflection infrared spectroscopy", Thin Solid Films, 347(1999) 195-200.

12) Q.-C. Zhang and Y.-G. Shen: "High performance W-AlN 
cermet solar coatings designed by modeling calculations and deposited by DC magnetron sputtering", Sol. Energy Mater. and Sol. Cells, 81(2004)25-37.

13) S.N. Ghosh, I.O. Parm, S.K. Dhungel, K.S. Jang, S.W. Jeong, J. Yoo, S.H. Hwang, and J. Yi: "Field-induced surface passivation of p-type silicon by using AlON films", Renewable Energy, 33(2008) 320-325.

14) L. Bois, P. L'Haridon, H. Wiame, and P. Grange: "Synthesis and characterization of high surface area oxynitride powders in the Al-V-O-N system", Mater. Res. Bull., 33(1998)9-19.

15) S. Dreer, R. Krismer, P. Wilhartitz, and G. Friedbacher:
"Statistical evaluation of refractive index, growth rate, hardness and Young's modulus of aluminum oxynitride films", Thin Solid Films, 354(1999)43-49.

16) W. Xiao and X. Jiang: "Optical ana mechanical properties of nanocrystalline aluminum oxynitride films prepared by electron cyclotron resonance plasma enhanced chemical vapor deposition", J. Cryst. Growth,264(2004) 165-171.

17) W.C. Oliver and G.M. Pharr: "An improved technique for determining hardness and elastic modulus using load and displacement sensing indentation experimentsl", J. Mat. Res., 7(1992) 1564-1583. 